\title{
Belphégor
}

\section{Os Irmãos Corsos no Brasil - Edição, texto e cultura}

\section{Rosângela Maria Oliveira Guimarães}

\section{OpenEdition}

\section{Journals}

\section{Edição electrónica}

URL: http://journals.openedition.org/belphegor/461

DOI: 10.4000/belphegor.461

ISSN: 1499-7185

\section{Editora}

LPCM

\section{Refêrencia eletrónica}

Rosângela Maria Oliveira Guimarães, « Os Irmãos Corsos no Brasil - Edição, texto e cultura »,

Belphégor [En ligne], 12-1 | 2014, mis en ligne le 15 juin 2014, consulté le 05 mai 2019. URL : http:// journals.openedition.org/belphegor/461 ; DOI : 10.4000/belphegor.461

Este documento foi criado de forma automática no dia 5 Maio 2019

\section{(c) (i) $\odot$}

Belphégor est mis à disposition selon les termes de la Licence Creative Commons Attribution - Pas d'Utilisation Commerciale - Pas de Modification 4.0 International. 


\title{
Os Irmãos Corsos no Brasil - Edição, texto e cultura
}

\author{
Rosângela Maria Oliveira Guimarães
}

1 Alexandre Dumas, o mais famoso folhetinista francês, tem um percurso consolidado na cultura brasileira, desde o século XIX, com a publicação de seus textos em jornais (folhetins) e depois em livros até os dias de hoje, circulando em vários tipos de edição. A estrutura folhetinesca atraente talvez seja uma das razões para a permanência dessa rede de textos.

\section{Edição francesa organizada por um biógrafo}

2 Les Frères Corses da Editora Gallimard ${ }^{1}$ tem 231 páginas, dividindo-se em "texto integral" até a 164, e um dossiê, a partir da 167 sobre Dumas (pai) e sua obra.

3 Trata-se de uma edição de bolso, com prefácio e notas de Claude Schopp, biógrafo consagrado do autor. Traz características materiais próprias: letras pequenas, espaçamento simples, em papel jornal, mas bem apresentada editorialmente. É bastante documentada pelo organizador, com informações sobre o livro e o folhetinista, assim como traz uma lista de edições de sua obra na França, das adaptações para o cinema, teatro e tevê e ainda bibliografia crítica sobre Dumas e seus folhetins, além de notas explicativas a respeito do romance em questão.

4 Tais cuidados acerca do livro revelam em primeiro lugar a preocupação de um biógrafo, em trazer informações para o leitor que enriqueçam a compreensão do texto apresentado; por outro lado, denota zelo em relação ao aspecto documental, situando e enriquecendo a publicação em causa, requisito que nem sempre comparece em edições populares, em sua maioria, inclusive as francesas. É claro que se trata de uma edição organizada por um biógrafo, a qual, mesmo preservando características de um livro popular, inova ao acrescentar informações sistemáticas que num suporte deste tipo não compareciam com tanto esmero. 
5 A edição, apesar de aproveitar o máximo de papel, tenta 'desafogar' as páginas iniciais dos capítulos, dando pausas entre os cabeçalhos e o início de cada um, numerados em algarismos romanos e sem títulos.

\section{Edições brasileiras}

6 Conforme mapeamento, a novela Os Irmãos Corsos foi publicada pelo Clube do Livro de São Paulo, em 1972, no mesmo volume de A Princesa Várvara, com o título A Família Corsa e tradução de Emilio Romeo e Nelly Cordes, 83 páginas. E também em edição infanto-juvenil pela Abril Cultural (1973), 172 páginas; pela Melhoramentos de São Paulo na década de 60 (1964, 119 p.), tendo sido localizada ainda uma sem data (101 p.). Não significa que o romance não tenha tido outras edições antes ou depois dos períodos mencionados.

7 Em geral, as edições brasileiras de romances-folhetins de Dumas durante o século XX mantiveram aspectos editoriais que não só reforçaram, muitas vezes, o destino popular dos textos, como revelaram certo exagero em aproveitar os mínimos espaços das edições, sobrecarregando visualmente os projetos gráficos das obras. Nota-se que não são reservadas novas páginas para o início de cada capítulo, acontecendo na mesma página que termina o anterior, com letras pequenas, espaços simples, etc.

8 No cotejo entre a tradução do Clube do Livro, A Familia Corsa (1972) e a edição francesa de 2007 da Gallimard percebe-se que a brasileira segue de perto o original. Trata-se de uma novela curta, com 164 páginas. Entre o original e a tradução mencionada, há poucas adaptações de linguagem do texto ao ambiente brasileiro, com acréscimos mínimos. Parecem até recriações textuais, a partir dos fatos narrados.

Chama-nos atenção que a edição francesa procura não sobrecarregar a visão do leitor, deixando espaços satisfatórios nos inícios de capítulos, sem aproveitar restos de página do anterior, o que preenche obviamente mais papel. Enquanto a tradução brasileira da década de 70 do século passado, por não seguir tais procedimentos, ocupa a metade das páginas: cerca de 84, dividindo a edição com outro romance de Dumas, A Princesa Várvara.

10 É claro que se tratava de uma estratégia usada pelos editores populares da época para economizar, sem deixar de vender mais. Por outro lado, um recurso de edição muito usado pelo Clube do Livro foi a criação de títulos para os capítulos, a partir de uma síntese que o tradutor/e ou editor fazia do enredo das sequências. Isso funciona como verdadeiras chaves e guias de leitura das obras, o que se considera uma estratégia positiva. Em A Familia Corsa (Clube do Livro), por exemplo, comparecem títulos de capítulos, como: 'A hospitalidade corsa', O quarto do ausente', 'As armas históricas', 'Inquietações maternas', 'O uivo na montanha', 'As ruínas do castelo de Vicente d'Istria', 'Uma tradição de família', entre outras soluções, aspecto editorial que não comparece na edição francesa consultada.

11 Por outro lado, entende-se que a denominação "juvenil" para Os Irmãos Corsos publicado pela editora Abril Cultural (Coleção Clássicos da Literatura Juvenil, 1973) se dá mais pela materialidade em si da edição que pelo texto. Do ponto de vista visual, várias ilustrações (espécie de desenhos em nanquim) traduzem em imagens aspectos importantes do texto narrado, enriquecendo o conjunto da obra ao mesmo tempo que sinalizam um direcionamento para esse tipo de público. Isso não significa que adultos também não tenham admirado e lido a referida coleção ao longo dos anos. A distribuição do texto na página também é outro aspecto que chama atenção, demonstrando cuidado em prol da 
boa apresentação da obra. Os espaços entre cabeçalhos e inícios de capítulo são satisfatórios. Todos os títulos aparecem em caixa alta, negrito, e a composição do texto é legível, bem distante do formato que o mesmo romance teve em edição popular pouco antes desse período.

\section{0 "escritor turista"}

12 Num primeiro momento d' Os Irmãos Corsos, Dumas explora o tema da viagem, amplamente utilizado em sua obra de um modo geral. Mais uma vez ele narra uma das possíveis/ou fictícias viagens que teria feito à região da Córsega. Lá, conhecendo uma família corsa tradicional, com suas histórias de "vendettas".

Seu biógrafo, Claude Schopp, em prefácio ${ }^{2}$ à recente edição francesa deste romance faz importantes esclarecimentos. Diz que a obra marca "a passagem das tentativas romanescas de Dumas de dramaturgo a romancista" (p. 7), e que escapa a classificações, "pois é curta para um romance e longa para uma novela" (idem).

14 A partir da análise de documentos e cartas a que teve acesso, Schopp diz que o texto sinaliza, em várias passagens, que Dumas provavelmente não esteve na Córsega, contrariando sua postura de "escritor turista", veiculada no início do romance. O país aparece muito forte em sua narrativa como um destino "desejado", conhecido apenas no campo da ficção.

15 Segundo Schopp, no fim de 1840, a Córsega existe para Dumas apenas enquanto "projeto editorial, Impressions de Voyage", para a realização do qual falta o essencial: dinheiro (p. 16). Está ligada a uma "viagem sonhada" e mais: "a uma invenção livresca". Aliás, Dumas mais tarde acaba reunindo em obra suas "Impressions de Voyage", considerada por Schopp "laboratório de prosa narrativa" (p.8).

16 Na leitura da obra Dumas, de um modo geral, repete-se um certo olhar "antropológico" sobre determinados ambientes, mostrando com minúcia tipos humanos e costumes. Na condição de narrador, descreve e apresenta julgamentos referentes a personagens e lugares, enquanto matéria narrativa, sem importância que os tenha conhecido ou não. Provavelmente, foram captados em leituras de obras de viagem ou de memorialistas.

17 Às vezes, fixa-se em cenas do cotidiano das personagens, ambientes, objetos, estabelecendo comentários a respeito de todo um conjunto. Tem-se a impressão de estar diante de uma verdadeira tela e não de uma página impressa, tal a visualidade que transborda de seu contar.

18 Uma vez apresentado o ambiente e os personagens de seus romances, Dumas, no caso de Os Irmãos Corsos, diz se fazer presente ali para saber mais a respeito das "vendettas", ou seja, encontrava-se na Córsega (ou se fazia presente ali no tempo da ficção) como o antropólogo que vai a campo para conhecer suas fontes.

\section{Os gêmeos nas edições francesa/Clube do Livro/Abril Cultural}

19 O romance aborda o tema da vingança, e de modo cômico, no que diz respeito à guerra dos Orlandi contra os Colona: a desavença entre as famílias se deu por causa da fuga de uma galinha para o galinheiro do vizinho. No entanto, as contendas familiares que a 
antecederam, no contexto narrativo, foram igualmente sangrentas e envolveram temas folhetinescos tradicionais, como invejas, tentativas de sedução, disputa por territórios, amores não correspondidos, assassinatos, entre outros assuntos.

Os gêmeos Luís e Luciano de Franchi, cada um em situações diferentes, se vêem envolvidos em contendas, em lugares opostos: um na Córsega "selvagem" e o outro na Paris civilizada do período.

Luciano, o corso/camponês, resolveu ficar na terra natal, cuida da mãe viúva, dos interesses da família e cultiva os costumes da região. Luis, cosmopolita, deixou a Córsega para viver em Paris e estudar advocacia. Era um "filho do livro", conforme demonstra sua biblioteca, em seu quarto na residência corsa, apresentada pelo narrador/hóspede: "Abri uma das estantes e encontrei nela livros de quase todos os poetas. Puxei uma das gavetas da secretária e encontrei nela uma história da Córsega e uma monografia sobre os meios necessários para se abolir a vingança, além de algumas poesias francesas e alguns sonetos italianos" (Ed. Clube do Livro, p. 83). Jovem deslocado da cultura dos antepassados, mas com o compromisso de ajudar a geração atual a resolver conflitos, aos moldes da instituição judicial vigente, designando o irmão como "árbitro" para tentar solucionar a briga entre os Orlandi e os Colona.

Eles são gêmeos idênticos e siameses (unidos pelo flanco - condição que influenciará a questão da telepatia entre ambos mais tarde), mas diferentes quanto à formação e visão de mundo. $O$ romance todo parece se construir a partir desta antítese dos lugares e dos personagens: a Córsega primitiva e a moderna Paris; o irmão camponês e o cosmopolita/ estudante, residente na capital francesa, cidade-símbolo do progresso e das ideias avançadas.

\section{A contenda Orlandi/Colona}

23 Advindo de uma tradição familiar em que a vingança marcou o convívio de seus antepassados, Luciano se ocupa de tentar a reconciliação de duas famílias da região, Orlandi e Colona, que há dez anos se enfrentavam, em consequência de uma contenda absurda: por causa de uma galinha em fuga, terminando em assassinato, conforme:

Os Orlandi reclamaram a galinha, mas os Colona declararam-na de sua propriedade. Os Orlandi ameaçam denunciar os Colona ao tribunal para que se apurasse a verdade. Nessa ocasião, a velha mãe, que tinha a galinha, torceu-lhe o pescoço e, atirando-a à cara da vizinha, exclamou: "Então, um dos Orlandi agarrou a galinha pelos pés e fez menção de golpear com ela a mulher que a tinha atirado na cara da Irma. Mas no momento em que erguia a mão, um Colona, que trazia infelizmente a espingarda carregada, atirou-lhe a queima-roupa, matando-o (Ed. Clube do Livro, p. 94).

Em seu papel, Luciano procura mostrar os equívocos que os envolvidos praticam em nome dessa rixa familiar, propósito que consegue após incontáveis negociações.

\section{Um amor não correspondido}

No passado, a família de Franchi se viu, por séculos, envolvida em contendas. Tudo teve início com um amor não correspondido do Sr. Giudice por Savília de Franchi, avó dos gêmeos. Uma união impossível, em virtude da incompatibilidade dos envolvidos: "No Castelo do Valle habitava o senhor de Giudice, tão odiado, quanto ela era amada, tão feio e 
disforme quanto ela era bela e gentil. Ele enamorou-se dela e, não se sentindo correspondido, mandou preveni-la que se não decidisse a aceitá-lo como esposo, dentro de um prazo estabelecido, empregaria a força para raptá-la" (Clube do livro, p. 100).

Savília fingiu que o amava, atraindo-o a seu castelo para fazê-lo prisioneiro. Durante três meses, despia-se diante da cela, numa espécie de provocação para que entendesse que era um homem feio e impróprio para ela. Mas Giudice fugiu e voltou para se vingar. Atacou o castelo, capturou Savília e a exibiu despida numa gaiola de ferro, no meio da floresta, sucedendo-se fatos terríveis que a levariam a morte.

O texto do Clube do Livro tenta amenizar o drama narrativo, informando que Savília, após capturada, morreu em decorrência da vergonha por ser exposta nua em público, enquanto a mesma sequência na Abril Cultural revela abuso sexual que a personagem teria sofrido naquela circunstância grotesca, bem como na edição francesa.

Savília foi presa e encerrada, despida como se apresentava a ele na prisão, numa gaiola de ferro, que Guidice mandou colocar num trívio na floresta, conhecido por "Cocca di Cilaccia". Depois que ele próprio a fechou nessa gaiola, afastou-se para sempre de sua vítima que se tornou alvo dos olhares cúpidos e das chacotas de todos os pretendentes, e não eram poucos, rejeitados por Savília e que Guidice convidara a assistir àquele espetáculo. Depois de algumas semanas, vencida pela raiva e pela vergonha, Savília morreu (Ed. Clube do Livro, p. 101).

Na edição da Abril Cultural, assim aparece:

Ao cabo de quinze dias, Guidice armou um pequeno exército de vassalos e assediou o castelo de Savília até tomá-lo. Isso feito, apoderou-se dela e exibiu-a nua dentro de uma grande jaula de ferro, numa clareira da floresta chamada Bocca di Cilaccia, oferecendo ele próprio a chave da jaula a todos os passantes. Ao fim de três dias dessa prostituição pública, Savília estava morta (Abril Cultural, p. 44).

\section{Na edição francesa:}

Ce supplice dura trois mois, se renouvelant deux fois par jour. Mais, au bout de trois mois, grâce à une femme de chambre qu'il séduisit, Guidice parvint à s'enfuir. Il revint alors avec tous sés vassaux, beaucoup plus nombreux que ceux de Savilia, prit le château d'assaut, et, s'étant à son tour emparé de Savilia, l'exposa nue dans une grande cage de fer, à un carrefour de la fôret appelé Bocca di Celaccia, offrant lui-même la clef de cette cage à tous ceux que sa beauté tentait en passant: au bout de trois jours de cette prostitution publique, Savilia était morte (p. 74).

\section{A teia das vinganças}

Os filhos de Savília, residentes em Ajaccio com um tio, foram "educados como corsos" e continuaram guerra contra os filhos de Giudice, durando quatro séculos. Terminou em data e hora precisos: " 21 de setembro de 1819, às 11 horas da manhã". 0 fim foi posto com a atuação dos pais dos gêmeos que eram primos. Os últimos Giudice tentaram a vingança final contra os Franchi, mas foram derrotados e mortos naquela data pelo casal Franchi, com a ajuda de criados e amigos. Desde então, viveram em paz não se envolvendo mais em contendas, a não ser para ajudar a resolvê-las. A Sra. de Franchi (também chamada Savília) estava grávida de sete meses no momento da última luta.

31 Neste ponto da narrativa, no conjunto de edições que segue esta perspectiva (Clube do Livro/Abril Cultural/ e a francesa), cessa em definitivo o tópico da vingança ancestral entre as famílias Franchi/Guidice. Mas na edição infantil o tema permanece como um novelo narrativo, desdobrando-se em várias outras conexões, até culminar com o 
assassinato de um dos gêmeos pelo perverso primo de Guidice, envolvendo muita ação, suspense e emoção, num final trágico para Luciano. Caberá ao pacato Luís vingar em seguida a morte do irmão: "Era superior em tudo ao barão e levava de vantagem a calma e a firme decisão de terminar para sempre essa "vendetta". De um golpe inesperado passou a espada pelos olhos de Guidice e logo depois varou-lhe o coração" (p. 99).

Um dos gêmeos sempre morre no desfecho de ambas as versões d' Os Irmãos Corsos. Na edição francesa consultada o ingênuo/cosmopolita/sonhador Luís é assassinado em duelo pelo experiente Chateau-Grand, cabendo a Luciano vingá-lo. Na infantil, a valentia deste o lança em combate direto com Guidice e seus comparsas e é morto em ação. E Luís põe fim à vingança que quase dizimou a família. A morte nessas circunstâncias, simbolicamente, é como se os irmãos não pudessem conviver no mesmo tempo/espaço, pelas mais diversas razões.

\section{Um quase triângulo amoroso}

A família de Franchi estava marcada pelo espírito da vingança. Mesmo procurando evitar discórdias, os gêmeos se vêem enredados na juventude em terríveis contendas.

Luís, filantropo, estudante de advocacia, residente em Paris, se envolve numa contenda com Chateau-Renault, por defender a "honra" da mulher de um amigo, a bela Emília, de um constrangimento público durante um jantar. Renault havia apostado que levaria ali uma jovem casada, cortejada por ele. Quando se viu exposta à tal situação, ela indignou-se diante da trama sórdida, solicitando a ajuda de Luís para retirá-la dali, o que causou a fúria do galanteador:

Já que me encontro aqui - prosseguiu a incógnita - agradecerei a este senhor, que me parece o anfitrião pela boa acolhida que me fez e como infelizmente não posso corresponder o ao seu gentil convite, pedirei ao Sr. de Franchi para me oferecer o braço e me reconduzir à minha casa (edição Clube do Livro, p. 132).

Por esse motivo, um duelo foi proposto por Chateau-Renault e aceito por Luís de Franchi. Mas o rapaz não tinha experiência com arma de fogo, e foi morto à queima-roupa por Renault. Segundo Schopp, na condição de "transplantado", o personagem "morre por ter vivido, num tempo e lugar onde dominam o cinismo e o individualismo (na cidade); ao contrário dos valores cavaleirescos (a honra da mulher de um amigo, por exemplo) correntes em sua ilha. A vida urbana que levava o privou do requisito primordial para se defender num duelo: saber manejar uma arma" (Les Frères Corses, p. 28).

E Luciano, que havia atuado como árbitro na contenda dos Orlandi e Corona, não hesitou em vingar a morte do irmão. Foi a Paris para desafiar Chateau-Renault a um duelo. Experiente no manejo de armas de fogo, mata Renault disparando um único tiro.

Dessa forma, tem-se no texto folhetinesco de Dumas a narração de contendas passadas e recentes, nas quais a família Franchi se achou envolvida de forma direta ou indireta.

\section{A edição do Clube do Livro/ a francesa: os acréscimos}

Nos capítulos XVI e XVII da edição francesa há alguns acréscimos em relação à brasileira do Clube do Livro. Por exemplo, no capítulo XVI, configura-se em acréscimo o seguinte diálogo entre Luís e o narrador/Dumas sobre a reação de Luciano, caso soubesse a verdade a respeito do duelo e os preparativos para acontecimento tão triste: 
J'essuyai la sueur qui me coulait du front.

- Maintenant, continua Louis, vous connaissez mon frère, n'est-ce pas?

- Oui.

- Que croyez-vous qu'il fasse s'il apprend que j'ai été tué en duel?

- Il partira à l'instant même de Sollacaro pour venir se battre avec celui qui vous aura tué.

- Justement, et, s'il est tué à son tour, ma mère sera trois fois veuve, veuve de son mari, veuve de ses deux fils.

- oh! Je comprends, c'est affreux!

-Eh bien, c'est ce qu'il faut éviter. Voilá pourquoi j'ai voulu écrire cette lettre. Croyant que je suis mort d'une fièvre cérébrale, mon frère ne s'en prendra à personne, et ma mère se consolera plus facilement, me croyant atteint par la volonté de Dieu, que si elle me sait frappé par la main des hommes. À moins que...

- À moins que?.... répétai-je.

- Oh! Non...., reprit Louis, j'espere que ce ne sera pas.

Je vis qu'il répondait à une crainte personnelle, et je n'insistai point.

En ce moment, la porte s'entrouvrit.

- Mon cher de Franchi, dit le baron de Giordano, j'ai respecté ta consigne tant que la chose a été possible; mais il est huit heures; le rendez-vous est à neuf; nous avons une lieue et demie à faire, il faut partir.

-Je suis prêt, mon três cher, dit Louis. Entre donc. J'ai dit à monsieur ce que j'avais à lui dire.

Il mit un doigt sur sa bouche en me regardant.

- Quant à toi, mon ami, continua-t-il- en se retournant vers la table et en y prenant une lettre cachetée; voici ton affaire. S'il m'arrivait malheur, lis ce billet, et conforme-toi, je te prie, à ce que je te demande.

- À merveille!

- Vous vous étiez charge des armes?

- Oui, répondis-je. Mais, au moment de partir, je me suis aperçu que l'un des chiens jouait mal. Nous prendrons, en passant, une boîte de pistolets chez Devisme.

Louis me regarda en souriant et me tendit la main. Il avait compris que je ne voulais pas qu'il fût tué avec mes pistolets.

- Avez-vous une voiture, demanda Louis, ou faut-il que Joseph aille en chercher une?

- J'ai mom coupé, dit le baron, et, en nous pressant un peu, nous tiendrons trois. D'ailleurs, comme nous sommes un peu en retard, nous irons toujours plus vite avec mes chevaux qu'avec des chevaux de fiacre.

- Partons, dit Louis (p. 138-139).

Já no cenário do duelo entre Luís e Chateau-Renaud, a edição francesa traz acréscimos em relação à brasileira (Clube do Livro), por exemplo:

Nous laissâmes Louis près de la voiture et nous nous avançames vers M. de Boissy et M. De Château-Grand [1]

Le baron de Giordano tenait à la main la boîte de pistolets.

Nous échangeâmes un salut.

- Messieurs, dit le baron Giordano, dans les circonstances pareilles à celles où nous nous trouvons, les plus courts compliments sont les meilleurs; car, d'um moment à l'autre, nous pouvons être dérangés. Nous nous étions charges d'apporter les armes, les voici; veuillez les examiner, nous venons de les prendre à l'instant même chez l'arquebusier, et nous vous donnons notre parole que M. Louis de Franchi ne les a pas même vues.

- Cette parole était inutile, monsieur, répondit le vicomte de Châteaugrand; nous savons à qui nous avons affaire.

Et, prenant un pistolet, tandis que M. de Boisy prenait l'autre, les deux témoins en firent jouer les ressorts tout en examinant le calibre. (p. 141-142).

No mesmo capítulo, Luís recomenda a Dumas (personagem igualmente): 
- Vous n'oublierez rien de ce que je vous ai demandé, me dit-il, et vous obtiendrez de Giordano, auquel je le demande, au reste, par la lettre que je lui ai remise, qu'il ne raconte rien, ni à ma [mère][1, ni à mon frère. Veillez aussi à ce que les journaux ne parlent point de cette affaire, ou, s'ils en parlent, à ce qu'ils ne mettent point les noms.

- Vous êtes donc toujours dans cette terrible conviction que le duel vous sera fatal? lui demandai-je.

- J'en suis plus convaincu que jamais; mais vous me rendrez cette justice au moins, n'est-ce-pas? que j'ai regardé venir la mort en vrai Corse.

- Votre calme, mon cher de Franchi, est si grand, qu'il me donne cet espoir que vous n'êtes pas bien convaincu vous-même (p. 142-143).

No final do último capítulo do romance os fatos dramáticos não se alteram, mas a narrativa diverge um pouco na sequência que narra os momentos que antecedem o duelo entre Luciano e Château-Renaud, entre a edição francesa e a do Clube do Livro, conforme:

M. de Château-Renaud, grâce à une grande puissance sur lui-même, paraissait calme; mais ceux qui l'avaient vu dans ces deux rencontres pouvaient cependant apprécier la différence.

De temps en temps, il jetait à la dérobée un regard sur Lucien, et ce regard exprimait une inquiétude qui ressemblait à de l'effroi.

Peut-être était-ce cette grande ressemblance des deux frères qui le préoccupait, et croyait-il voir dans Lucien l'ombre vengeresse de Louis.

Pendant qu'on chargeait les pistolets, je le vis enfin tirer sa main de sa redingote; sa main était enveloppée d'un mouchoir mouillé qui devait en apaiser les mouvements fébriles.

Lucien attendait l'oeil calme et fixe, en homme qui est sûr de sa vengeance.

Sans qu'on lui indiquât sa place, Lucien alla prendre celle qu'occupait son frère; ce qui força naturellement M. de Château-Renaud à se diriger vers celle qu'il [1] avait déjà occupée.

Lucien reçut son arme avec un sourire de joie. M. de Château-Renaud, en prenant la sienne, de pâle qu'il était, devint livide.

Puis il passa sa main entre sa cravate et son cou comme si sa cravate l'étouffait [...]

- Y êtes-vous, messieurs? demanda M. de Châteaugrand.

- Oui, répondit Lucien.

M. de Château-Renaud fit un geste affirmatif. Quant à moi, n'osant envisager cette scène en face, je me retournai. M. de Château-Renaud était étendu sur le sol, tué raide, sans avor poussé un soupir, sans avoir fait un mouvement.

Je m'approchai du cadavre, mû par cette invincible curiosité qui vous pousse à suivre jusqu'a au bout une catastrophe; la balle lui était entrée à la tempe, à l'endroit même qu'avait indiqué Lucien.

Je courus à lui; il était resté calme et immobile; mais, en me voyant à sa portée, il laissa tomber son pistolet et se jeta dans mes bras.

- Oh! mon frère, mon pauvre frère! s'écria-t-il.

Et il éclata en sanglots.

C'étaient les premières larmes que le jeune homme eût versées (p. 164).

Em português, o mesmo trecho sobre o assassinato de Château-Renaud por Luciano, para vingar o irmão gêmeo, morto na semana anterior, fica bastante resumido e recriado, conforme:

Após uma troca de cumprimentos, desceu do cavalo. Suas testemunhas fizeram o mesmo e aproximaram-se de nós.

As preliminares do duelo foram rapidamente estabelecidas; Luciano e o Sr. De Château-Renaud dirigiram-se aos seus lugares, marcado por um lenço.

Como fizera alguns dias, na ocasião do duelo que fora fatal para Luís de Franchi, o Sr. Château-Grand bateu palmas:

- Uma... duas... e três! 
As garruchas explodiram ao mesmo tempo e, enquanto Luciano permanecia de pé, o Sr. Château-Renaud, depois de ter cambaleado, abateu-se sobre os joelhos.

Suas testemunhas precipitaram-se em seu socorro, mas tiveram apenas o tempo de recebê-lo em seus braços, pois do contrário, teria caído ao chão. Deitaram-se na relva e trataram de reanimá-lo, mas tudo foi inútil. O Sr. Château-Renault era cadáver.

Um fio de sangue escorria-lhe da testa, onde aparecia o pequeno furo produzido pela bala de Luciano.

Luciano de Franchi deixou cair a garrucha e lançou-se nos meus braços, soluçando. Eram as primeira lágrimas, que vertia, depois da morte do irmão (Clube do Livro, p. 157-158).

\section{As edições brasileiras - o que permanece}

Chama-nos atenção a recriação nos títulos dos capítulos entre a edição do Clube do Livro e a da Abril Cultural. Alguns coincidem, mas outros são reinventados de maneira poética pela Abril. Por exemplo: Cap. X (Abril Cultural): "A vendetta fracassada". O mesmo no Clube do Livro se chama: "A reconciliação é mais rara do que a vingança"; cap. X, Abril Cultural: "O pacto estranho dos de Franchi"; cap. X, Clube do Livro, "Uma tradição familiar".

A edição juvenil da Abril Cultural traz em relação à francesa e a tradução do Clube do Livro acréscimos textuais e até capítulos que se configuram em verdadeiras recriações, em relação ao original francês. Por exemplo, a respeito da semelhança física entre os irmãos gêmeos, Luciano comenta: "Quando éramos crianças, nossos pais eram obrigados a colocar nas minhas roupas e nas de Luís um sinal que nos distinguisse" (Abril Cultural, p. 21). No Clube do Livro, o narrador/personagem confunde ambos: “- Desculpe-me - se não respondi logo ao seu gentil cumprimento, mas confesso-lhe que, quanto mais o observo, tanto mais fico em dúvida se é ao Sr. Luís ou ao Sr. Luciano de Franchi que tenho a honra de falar" (p. 123).

O capítulo "A vendetta fracassada" é praticamente recriado na edição juvenil. Utilizandose apenas do motivo da caçada de Luciano e seu serviçal, próximo ao território dos Colona e dos Orlandi, o tradutor/ou editor amplia a narrativa, contando que um simples disparo para abater uma caça reacende o enfrentamento das duas famílias, cada uma a achar que havia sido atacada pelo vizinho rival:

O tiroteio que se seguiu foi espantoso. Balas passaram zunindo pelo meu ouvido e iam se cravar nas paredes de uma casa vizinha. Durante um minuto só se ouvia o barulho e se via o fogo cuspido por carabinas e pistolas empunhadas pelas duas famílias. Eu não podia recriminar os Colona, pois agora se defendiam da pontaria certeira os Orlandi (Abril Cultural, p. 61).

E Luciano, no meio do fogo cruzado, grita:

- Houve um terrível engano! - gritou. - o tiro que ouviram na montanha foi disparado por mim contra um faisão! Orlandi não atirou em ninguém! Mandei que Grifo avisasse na aldeia sobre nossa caçada, mas algo deve ter acontecido a ele, pois não o fez! Não permitam que um engano ponha a perder o que havíamos combinado! Lembrem-se de suas esposas e filhos! (Abril Cultural, p. 61).

Assim todo o capítulo prossegue a partir do tópico recriado. Certamente, o tradutor/ou editor ampliou tal aspecto com base no tema da vendetta que as duas famílias travavam há anos. Desse modo, de maneira criativa, "recheou" a trama introduzindo nova batalha, por 
motivo banal, que quase quebrou o pacto de paz firmando um dia antes entre as famílias rivais, graças aos esforços de Luciano.

No primeiro capítulo da edição da Abril Cultural cerca de meia página é criada para tratar do diálogo entre o mordomo da família Franchi e o narrador/aventureiro (o próprio Dumas), perguntando se o viajante se sentiu bem ao cavalgar pela "velha Córsega", rumo à residência da família Franchi, finalizando com o comentário do viajante: "Que alívio! Estava tão cansado que nunca como aquele momento apreciei a velha hospitalidade corsa" (Edição Abril, p. 13).

Outro trecho "alongado" se dá com a introdução do tema da reincidência da vendetta entre as duas famílias, por causa do equívoco dos tiros disparados por Luciano contra um faisão durante uma inocente caçada na volta para casa. Usando as "brechas" que o próprio enredo folhetinesco deixa sempre em aberto, o narrador inventa uma contenda intermediária entre as famílias rivais, pelo motivo já mencionado.

O acréscimo parte da metade da página 55 e vai até a 67, ou seja, cerca de 11 páginas acrescidas em relação à edição francesa consultada, o que demonstra uma inconfundível habilidade dos adaptadores ou editores de "esticarem" tais enredos folhetinescos, sem romper com o núcleo narrativo central. Ao contrário, criam situações "verossímeis" em relação ao que vinha sendo narrado.

51 Em geral, o leitor não tem a preocupação de comparar ou não encontra meios para isso, $\mathrm{e}$ no caso do romance em questão, acredita que houve o conflito entre as famílias inimigas, antes da reconciliação conseguida por Luciano, com direito à assinatura "de termo de reconciliação". No combate, Luciano e o criado saem feridos com tiros de raspão e o incidente é descrito por Luciano: “ - Ufa! exclamou ele. - Pensei que não pudesse conseguir! Tanto Colona quanto Orlandi estavam empedernidos como ursos. Em vez de paz, queriam era beber o sangue do inimigo!" (Abril Cultural, p. 64).

No final do capítulo 9, "A vendetta fracassada", o narrador/viajante conclui suas impressões sobre o combate há pouco enfrentado: "Depois de um bom banho quente e uma abundante ceia, fomos imediatamente para a cama. Durante muito tempo, em meu sonho, ainda pulei de telhado em telhado para escapar às balas mortíferas com que enfurecidos corsos desejavam me mandar para o outro mundo. Também no sonho tive sorte, e acordei ileso" (Abril Cultural, p. 67).

53 O capítulo 10 (O pacto estranho dos de Franchi) narra as aparições dos antepassados dos Franchi mortos. Há uma conversa de Luciano com o hóspede parisiense sobre o assunto, explicando como seus antepassados de linhagem masculina se comunicam em momentos de crise ou na hora da morte. Segundo ele, esse fato teria começado com um pacto de sangue feito no passado entre os dois filhos de Savília (a pretendida de Guidice):

- Esses dois filhos cresceram e, habituados a contar apenas um com o outro, estimavam-se muito. Juraram entre si que nada os poderia separar, nem mesmo a morte. Um dia, resolveram escrever, com o próprio sangue num pedaço de pergaminho que trocaram, o seguinte juramento: "O primeiro a morrer aparecerá ao outro, quer no instante de sua morte, quer depois, nos momentos mais importantes da vida do outro (Abril Cultural, p. 72).

54 E concluindo o capítulo, de modo mais descontraído, após o assunto sobrenatural, há uma espécie de jantar de confraternização celebrando a vida de cada um, ameaçada no dia anterior pelo tiroteio entre as famílias rivais. Editorialmente, se configura em acréscimo em relação à edição francesa: 
- Ótimo. Estou com uma fome de lobo.

- $\mathrm{O}$ tiroteio de ontem deve lhe ter aberto o apetite - disse Luciano sorrindo.

- Sim, mas para a comida - respondi. - Não para os outros tiroteios. Vim à Córsega de visita, não para ser enterrado.

[...] - Ótimo. Mas é melhor se sentarem e comerem, senão chegarão atrasados à cerimônia.

Luciano e eu não esperamos uma segunda sugestão. Sentamo-nos à mesa farta e, contentes, homenageamos a saborosa comida corsa.

Pouco antes das dez horas, caminhávamos ambos energicamente pela bonita praça de Sullacaro (Edição Abril Cultural, p. 73).

Chama-nos atenção a abundância de diálogos e a teatralização que o romance apresenta, típicos das tramas folhetinescas.

No capítulo 11, “A reconciliação”, flagra-se outro acréscimo em relação à edição francesa. Trata-se de cerca de duas páginas e meia em que Graziela Colona chega aflita à casa de Savília de Franchi, com a possibilidade de o pai não aceitar seu namoro com Bonomi Orlandi, já que até pouco tempo eram famílias inimigas. Graziela pede ajuda aos de Franchi em mais esta empreitada, como também a de Alexandre, o visitante ilustre, que auxiliou na resolução do conflito anterior:

Os diálogos assim se constroem:

A Sra. Savília assim se dirige a jovem aflita:

“- O que você quer me falar é segredo ou pode ser dito aqui mesmo?

A moça hesitou.

- Não, não é segredo. Ou, pelo menos, quero que todos o saibam o mais rápido possível.

[...] - O caso é que... - começou nervosamente. - Quer dizer... Bononi Orlandi e eu nos amamos...

- Sim - encorajou-a a Sra. de Franchi. O amor é sempre uma boa coisa.

- É - concordou ela desanimadamente -, mas acho que papai me arrancará os olhos quando souber que nos amamos e queremos casar-nos" (Abril Cultural, p. 81).

E na sequência o próprio Alexandre é convidado a ajudar nas negociações:

[...] - Como?! - exclamou Graziella. - O senhor vai deixar-nos?

- Sim- respondi, surpreendido com aquela reação. - Tenho compromissos em

Paris.

- Por favor, não vá agora - pediu Graziella com olhos suplicantes.

- Por quê? - perguntei espantado.

- Sua presença nos deu sorte - falou ela muito séria. - 0 senhor trouxe a paz consigo. Por que não fica mais um dia para ajudar-nos a convencer meus pais?

Lá estava a velha e infalível superstição corsa!

- Por que acha que eu poderia ajudar? - perguntei, achando graça nas palavras de Graziella.

- Sei que poderia - disse ela. - Por favor, fique, senhor!

Hesitei um momento. Por fim me decidi.

(Abril Cultural, p. 83).

Veja-se que na edição francesa o tópico da partida de Alexandre da casa da família de Franchi a Paris para assistir à peça Um Casamento no Reinado de Luís XV é explorado pelo editor da Abril para "esticar" o enredo. É no momento em que o personagem/narrador comunica sua decisão aos de Franchi que Graziella aparece pedindo ajuda. Este fio narrativo dá origem ao capítulo seguinte (de acréscimo) da Abril Cultural em relação ao texto francês, intitulado "Graziella e Bonomi". De maneira coesa, o editor brasileiro/ tradutor cria o capítulo, de modo que o leitor é levado a acreditar que tais peripécias, em relação aos respectivos personagens, acontecem na narrativa original. Neste capítulo, 
Luciano tenta convencer o pai de Graziella a aceitar o romance da jovem com Bonomi Orlandi, que recusa terminantemente. Árbitro em mais essa negociação, ele pede paciência ao casal apaixonado. parte. Permanece a essência do texto francês quanto ao local do duelo, "no bosque de Vincennes", o posicionamento dos adversários, os sinais dados pelos "padrinhos" para o início do combate. Isso só comparece no final do capítulo, nos dois últimos parágrafos, porque por cerca de quase duas páginas há o diálogo entre "Chateaugrande" e De Boissy, padrinhos de Chateau-Renaud, com Alexandre e Giordano, os de Luís de Franchi. Em capítulo anterior, mais um acréscimo para justificar o presente desdobramento narrativo, os padrinho de Luís haviam solicitado a Chateu-Renaud, através de seus representantes, que desistisse do duelo, já que Renaud tinha experiência nesse tipo de confronto e Luís não sabia manejar nenhuma arma. Portanto, seria uma espécie de desatino/suicídio da parte do jovem aceitar tal desafio. Mas o rival foi implacável:

Ora meu caro - disse ele , fui ofendido publicamente por Luís de Franchi. Seria uma grande covardia de minha parte esquivar-se a esse ajuste de contas.

- De nada adiantou minha sugestão de que Luís não tivera intenção de ofendê-lo:

Ouça, Chateaugrand - respondeu ele com irritação -, minha decisão é inarredável.

Por favor, não interfira em assuntos que dizem respeito à minha honra. Contudo, se 
não quiser servir-me de padrinho é só dizer: tratarei de escolher outro (Abril

Cultural, p. 139). "brechas" do texto que traduz e, em certos pontos até recria, enredos folhetinescos tão
atraentes quanto os que serviram de inspiração no texto original, preservando o núcleo
narrativo da história e enriquecendo a tradução brasileira com novos suspenses, quadros e tramas. Assim tem-se um texto folhetinesco, por sua própria natureza, já expandido, mas outras "franjas" vão sendo acrescentadas, sem que ele perda o encanto original. Diríamos que está sempre em renovação.

68 A análise comparativa entre a edição francesa e a da Abril Cultural demonstra que o texto de Dumas em análise permanece intenso/compacto, com alguns acréscimos/recriações que a estrutura folhetinesca permitiu ao tradutor/adaptador, sem que os fios narrativos fossem rompidos. Ao contrário, tais soluções apresentadas, em momentos precisos do texto, enriqueceram ainda mais o enredo, trazendo mais aventuras e suspense à narrativa.

69 A pesquisa ainda mostra, no âmbito das três edições consultadas (a francesa, a do Clube do Livro e a da Abril Cultural), que o texto não foi "sacrificado" em benefício de nenhuma faixa etária de leitor. Ele permanece com toda pujança nos dois tipos de edições/ traduções brasileiras. De forma que a Abril Cultural não o "mutilou", processo comum em adaptações de clássicos para o público infanto-juvenil em Língua Portuguesa. A beleza e a força deste texto folhetinesco permanecem inalteradas nas versões brasileiras citadas e o leitor só tem a ganhar com isso, quer seja juvenil ou adulto. Sim, porque acredita-se que, mesmo havendo uma tentativa de delimitação de público, como divulgado nas propagandas dos volumes, esta fronteira é tênue: adultos e jovens podem e devem ter lido os dois tipos de edição, sem hierarquias.

\section{Os Irmãos Corsos (edição da Melhoramentos)}

O primeiro aspecto a se notar é que os títulos dos capítulos da edição infantil de Os Irmãos Corsos da Editora Melhoramentos são bastante sugestivos, do ponto de vista folhetinesco. Chamam atenção pela síntese que transmitem e a ideia de aventura, suspense, drama. Entre outros, destacam-se: 'Ódio antigo'; 'O ataque’; ‘A operação'; ‘Estranhezas'; ‘Amor...'; 'O pesadelo'; ‘A carta'; ‘As ruínas'; ‘A saída secreta'; ‘A gruta do tarava'; 'Planos de campanha'; ‘A fuga'; ‘Alucinação’; ‘Suspeitas’; ‘O médico’; ‘O pombo-correio'.

71 Na edição do Clube do Livro, que se aproxima mais da Abril Cultural e da francesa analisadas, os títulos dos capítulos sugerem um novo rumo narrativo, a exemplo de: 'Hospitalidade corsa'; 'O quarto do ausente'; 'Luciano de Franchi'; 'As armas históricas'; 'Inquietações maternas'; 'O uivo da montanha'; 'As ruínas do Castelo de Vicente d'Istria' (sic); 'Um salteador'; 'A reconciliação é mais rara do que a vingança'; 'Uma tradição de família'; ‘A reconciliação’; ‘Luís de Franchi’; ‘A aposta do Sr, Chateau-Renault'; ‘A causa da 
contenda'; 'Preliminares de um duelo; 'O dramático duelo’; ‘A presença de Luciano’; ‘Um relato impressionante'; 'As primeiras lágrimas de Luciano'.

A própria configuração dos capítulos entre uma edição e outra (brasileiras) parece sugerir que a narrativa em questão segue rumos diferentes e, em alguns casos, os fatos narrados são invertidos e recheados com novos aspectos, numa clara demonstração de que o texto folhetinesco aí é móvel e dinâmico, permitindo colagens e ajustes que só o enriquecem.

73 Nota-se que o foco narrativo que dá sustentação ao enredo difere de uma edição a outra. Na do Clube do Livro, assim como a da Abril e a francesa, três núcleos narrativos estão bem demarcados, dando sentido à trama. Primeiro, tem-se um narrador/viajante que visita a Córsega e conhece a tradicional família Franchi, envolvida no passado em contendas, mas que no momento da narrativa se dedica a ajudar os habitantes locais a resolverem conflitos entre si. O narrador e um representante da família Franchi, Luciano, por exemplo, se empenham em promover a paz entre os Colona e Orlandi. Os fatos acontecem em ambientes diferentes: na Córsega rústica e em Paris, signo do progresso.

No núcleo parisiense, está em foco a disputa pelo amor de uma mulher casada. 0 filantropo Luís de Franchi se apaixona pela mulher de seu amigo, a bela Emília, mas não ousa confessar esse amor, em respeito à reputação da jovem. Ao contrário, o galanteador Chateau-Renauld a tenta envolvê-la numa trama de sedução que a comprometeria. É salva da desventura por Luís, que paga com a própria vida pela interferência no caso. Alexandre (o narrador viajante) havia conhecido a família do jovem na Córsega e o acompanha na capital francesa, durante os desdobramentos do conflito entre rivais que termina em tragédia.

75 No último capítulo da trama, Luciano, que também tem o dom da telepatia, vê os lances do duelo e seu irmão sendo assassinado. Vai a Paris e vinga sua morte, atingindo Renauld em duelo. A telepatia é apresentada em lances dramáticos. Talvez se trate de uma alusão difusa à Ciência da época ao tratar do assunto. Em linhas gerais, consiste na capacidade de comunicação entre duas pessoas, independente das distâncias ${ }^{3} .0$ interessante é observar como o tema se insere e se desdobra para dar coesão e movimento à trama.

Ainda na edição infantil parece haver uma reviravolta dos fatos narrados. 0 tema da vingança permanece, mas apresentado sob outro ângulo. Sendo acrescentado um outro bastante convincente: os gêmeos deverão vingar o massacre de sua família, executando o barão de Guidice, responsável por matar seus pais em emboscada. Outro assunto fundamental no enredo e que dá movimento à trama é o ódio que surge entre os irmãos, em virtude da disputa pelo amor de Emília, e também em decorrência das diferenças de formação de ambos, afetando o relacionamento.

Um tópico folhetinesco, mencionado parcialmente na edição francesa e na do Clube do Livro (mas não sem consequências drásticas), desenvolve-se e ganha força na infantil. Trata-se da recusa de Savília de Franchi ao pedido de casamento do feioso barão Giudice, dando origem à fúria desenfreada do cidadão. Ele não só a captura e a mantém prisioneira até morrer de tristeza, como ataca anos depois os últimos descentes da família numa emboscada, os primos Vítor de Franchi e esposa. Ela acabara de dar à luz a gêmeos. Tragédia que por sua vez irá provocar mais tarde a ira dos gêmeos corsos contra o mesmo barão, culminando com o desfecho final do romance.

78 Os motivos narrativos muitas vezes se misturam nas edições citadas, ganham novos rumos e o inusitado acontece. Por exemplo, na versão infantil o barão de Guidice se enamora por Emília, dama que havia motivado o duelo entre Luís e Chateau-Renauld em 
Paris um pouco antes, tópico comum a todas as edições consultadas. Na verdade, a jovem vai à Córsega porque teria se irritado com a notícia do duelo, por sua causa. No enredo infantil, Emília é a personagem que desperta sucessivas paixões. Luciano também se enamora ao vê-la, embora já a conhecesse por telepatia, por estar ligada a seu irmão.

Tais exemplos de bifurcações narrativas demonstram que entre as edições analisadas ora há uma espécie de "congelamento" ou "alongamento" de determinados tópicos narrativos, que vão direcionar os rumos do enredo, tanto na edição infantil como nas demais. E no final todas se entrelaçam e dialogam, como se uma fosse o desdobramento da outra, priorizando cenas e soluções de um mesmo texto.

\section{Abundância de motivos folhetinescos}

A edição infantil é farta em motivos folhetinescos. Por exemplo, existe um capítulo denominado "A saída secreta" (XIII) e trata-se de um acréscimo bem conseguido em relação às demais edições da história, a ponto de existir nas ruínas do velho castelo da família de Franchi uma entrada subterrânea. Ali foram guardadas durante anos as lembranças dos antepassados dos gêmeos pelo médico Enrico Paoli:

o grupo, acompanhando o médico que trouxera uma lanterna furta-fogo, que mal os orientava no meio daquele montão de entulho que atravancava tudo, dirigiu-se para um ângulo da parede.

o homem abaixou-se, removeu com certa dificuldade um bloco de reboco, apertou uma mola oculta e a parede moveu-se silenciosamente.

- Como isso ainda funciona, hein?...

-É que tenho tido o cuidado de engraxar as molas de quando em quando. Ninguém sabe o que pode suceder amanhã... aliás há vinte e um anos que espero poder entregar a Luís e Luciano o que resta de seus domínios.

- Mas... depois de passarmos, a porta ficará aberta?...

- Não, ela volta automaticamente ao lugar.

[...] Todos eles penetraram no corredor. Em determinado lugar se detiveram. Havia ali, bem dissimulada pela parede de pedra que dava num corredor bastante íngrime (Edições Melhoramentos, p. 48).

$81 \mathrm{Na}$ arquitetura dos fatos narrados, fazendo parte do plano de vingança planejado pelo médico, pelos pais adotivos dos gêmeos e os próprios, o barão e seus comparsas passam a ser atacados sistematicamente. Até que o perverso primo de Guidice, Tomás, descobre que o sinal deixado em cada emboscada era conhecido: "O entalhe do cabo é o mesmo das adagas que nos têm assombrado. Lembra-se?... Elas vieram do saque do castelo do conde de Franchi" (p. 77). E os gêmeos entram também na mira do barão. Há um “ir e vir" da narrativa surpreendente, dando ritmo e atraindo a atenção dos leitores.

O ódio entre os gêmeos e a disputa deles pelo amor de Emília são introduzidos e trabalhados na versão infantil, diferenciando-a das demais. Luciano passa a ter inveja de Luiz por não ter recebido a educação esmerada que o irmão teve acesso na capital francesa. Trata-se de temas longevos, que não comparecem nas edições brasileiras (para adultos) consultadas e a francesa em questão.

Em certo momento, a edição infantil toma outro rumo. $O$ ódio entre irmãos é um assunto que está presente na narrativa bíblica, como o de Abel e Caim; em tópicos de literatura universal; na brasileira, em Esaú e Jacó ${ }^{4}$ de Machado de Assis, insinuando-se ainda em Os Dois Irmãos ${ }^{5}$ de Milton Hatoum. Nos textos brasileiros esse ódio se acirra com a disputa pelo amor da mesma mulher, semelhante aos irmãos corsos. Ao que parece, a adaptadora 
da história infantil, Guiomar Rocha Rinaldi ${ }^{6}$, jogou com esse tema longevo, introduzindo-o na narrativa folhetinesca em questão. Ficou bem resolvido na estrutura dramática do folhetim. É convincente nos argumentos usados no texto, conforme:

Luciano porém sofria. Em sua imaginação uma ideia doentia se criara e desenvolvera. Luís tira-lhe a melhor parte da vida. Tira-lhe o amor da única mulher que havia amado (p. 84).

Luciano: "- Nunca precisei dele. Vivi aqui no mato como um camponês rude enquanto o tal senhor meu irmão se pavoneava em Paris. Sempre o odiei. Odiei-o nos sonhos porque ele vivia uma vida que não me fora dado a viver. Odeio-o agora por ser quem é e como é. Pode ir embora corso desnaturado" (p. 86).

Emília é capturada por Guidice no momento em que percebe a discórdia entre os irmãos e resolve voltar a Paris, para não dificultar o plano de vingança deles, conforme diz em bilhete a Luís: "Meu querido noivo, você tem de cumprir uma missão de tal maneira sagrada que minha presença ai só pode atrapalhar. Resolvi ir a Paris onde ficarei à sua espera. Creia que o amo hoje mais que ontem e muito menos que amanhã. Emília" (p. 88).

As características folhetinescas permanecem em destaque. Para salvar Emília, Luís se disfarça de vendedor de jóias, entra no palácio de Guidice, mas é capturado. Ao contrário das demais edições, Emília é viúva e não comprometida. Recebia numa luxuosa casa em Paris convidados ilustres, inclusive Chateau-Renand, que aposta com amigos que a levaria a um jantar na casa de um conhecido: "Emília ficara viúva muito moça e vivia com seu pai, o marquês de Verona" (p. 30).

No processo adaptativo mais amplo, "um jornalista" frequenta também o nobre salão. Nota-se que o motivo da aposta do galanteador permanece na edição da Melhoramentos, causa do duelo entre Luís e Chateua-Renand, mas não trágico como no original francês. Consta no texto que Emília se revolta com a mentira de Chateau-Renand:

Já lhe disse que não aceito! Você ficou de me levar à casa de minha amiga e traiçoeiramente me trouxe para cá.

- bem, querida Emília. Mas... já que veio, o que lhe custa ficar?... É um papel ridículo o que está fazendo. Não é nenhuma criança... (p. 34).

\section{E desabafa:}

Agora entendo tudo. Ele comprometera-se a levar-me à casa de uma amiga. Confiei que fosse pelo menos um cavalheiro. Enganei-me! Mas... aqui não fico! Senhor Luís Duprès quer me acompanhar até minha casa? (p. 35).

No encadeamento de motivos folhetinescos acrescentados, há um capítulo intitulado 'A carta'. O Sr. Duprès recebe uma correspondência do médico Enrico de Paoli, pedindo-o que vá à Córsega com Luís, para a revelação do segredo de família. Tal combinação clássica, carta e segredo, dita os rumos de toda a sequência narrativa posterior. No rol de adaptações, consta que o pai adotivo de Luís possuía um “iate”, inclusive para ir à Córsega a passeio. Na grande teia de enredos, entre outros motivos, há entradas e saídas secretas do castelo dos Franchi, que movimentam e dão suspense à trama. No momento da invasão do castelo da família, Paoli escapa com as crianças por uma saída secreta. Por outro lado, a memória deles é preservada numa gruta nas ruínas do velho castelo, com acesso secreto. E nada mais folhetinesco do que o leitor ser surpreendido com o aparecimento de um diário, em determinado ponto da narrativa. É item indispensável em qualquer enredo de folhetim! Pois, há um em poder do médico que trata sobre a trajetória dos Franchi, só entregue aos gêmeos após a maioridade. Consta que na "última parte continha a narrativa completa dos acontecimentos sucedidos com a família de Franchi desde que a bela Davília recusara a mão do barão de Guidice" (p. 57). 


\section{Considerações finais} romance de Alexandre Dumas. Na ausência de outra versão francesa que dialogue com ela mais de perto, pode-se se dizer que a analisada aqui (organizada por Claude Schopp) se distancia ao mesmo tempo que a complementa em alguns aspectos. As demais traduções brasileiras da história, do Clube do Livro e a da Abril Cultural, seguem o texto francês citado, embora seja visível a 'audácia' criativa da edição da Abril Cultural, expressa, via acréscimos e recriações, em contraponto à tentativa de fidelidade do Clube do Livro. E no meio desse emaranhado de textos/rede há ainda um folheto de cordel ${ }^{7}$ nordestino sobre o tema. Isso se configura em outro desdobramento da história de Dumas entre nós e será matéria de texto futuro sobre o assunto.

Do ponto de vista da leitura, constata-se que a novela continua sendo lida no Brasil durante o século XX, contemplando três gerações de leitores: a criança, o adolescente e o adulto, e consequentemente sendo veiculada em tipos de edições diferentes para se adequar a esses segmentos, com suas especificidades e atrativos. Isso comprova a boa recepção d' Os Irmãos Corsos na cultura brasileira. Como se pode ver, um texto traduzido para todas as faixas etárias de leitores, mesmo abordando tema central tão árduo, como a vingança e suas consequências.

\section{BIBLIOGRAPHIE}

Dumasy-Queffélec, Lise. Le Roman-feuilleton français au XIXe siècle. Disponível em: http:// etc.dal.ca/belphegor/vol7_no1/quesaisje.html. Acesso em: 13 nov. 2011.

Dumasy-Queffélec, Lise.. "Du roman-feuilleton au feuilleton-télévisé: mythe e fiction”. In MIGOZZI, Jacques (dir.) De l'écrit a l'écran. Littératures populaires: mutations génériques, mutations médiatiques. Limoges: PULIM, 2000.

Fonseca Dos Santos, Idelette Muzart. "Monte Cristo, du roman au livre de colportage: traduction poétique et populaire d'Alexandre Dumas au Brésil». In: Migozzi, Jacques (Org.). Le Roman Populaire en Question(s). Limoges: Pulim, 1997.

Hatoum, Milton. Dois Irmãos. São Paulo: Companhia das Letras, 2006.

Meyer, Marlyse. Folhetim: uma história. São Paulo: Companhia das Letras, 1996.

Pires Ferreira, Jerusa. Cavalaria em Cordel. São Paulo: Hucitec, 1993.

Pires Ferreira, Jerusa. Cultura das Bordas: edição, comunicação, leitura. São Paulo: Ateliê Editorial, 2010.

Pires Ferreira, Jerusa. O Livro de São Cipriano: uma legenda de massas. São Paulo: Perspectiva, 2002. 
Pires Ferreira, Jerusa. "Das Águas da Memória aos romances de Milton Hatoum: evocação, e transferência de cultura”. In: Arquitetura da Memória. Org. Maria da Luz Pinheiros de Cristo. Manaus: Editora da Universidade Federal do Amazonas/ UNINORTE, 2007. pp. 248-257.

Edições brasileiras consultadas do romance Irmãos Corsos de Alexandre Dumas:

Dumas Alexandre. A Família Corsa. Trad. Emílio Romeo e Nelly Cordes. São Paulo: Clube do Livro, 1972.

Dumas Alexandre. Os Irmãos Corsos. Trad. Augusto de Sousa. São Paulo: Saraiva, 1954.

Dumas Alexandre. Os Irmãos Corsos. Trad. Guiomar Rocha Rinaldi. São Paulo: Edições Melhoramentos, 1964.

Dumas Alexandre. Os Irmãos Corsos. Adaptação de Myriam Campello. São Paulo: Abril Cultural, 1973 (Coleção Clássicos da Literatura Juvenil).

Edição francesa

Les Frères Corses, Préface de Claude Schopp, Paris, Gallimard, 2007.

\section{NOTES}

1. Collection Folio Classique, 2007.

2. Cf. Les Frères Corses, Prefáce de Claude Schopp, Paris, Gallimard, 2007, p. 7-30.

3. Telepatia - termo cunhado por Frederick W.H. Myren em 1882.

4. Cf. Machado de Assis. Esaú e Jacó. Editora Garnier, 2005.

5. Cf. Hatoum, Milton, Dois Irmãos. São Paulo, Companhia das Letras, 2006. Cf. ainda Pires Ferreira, Jerusa. "Das Águas da Memória aos Romances de Milton Hatoum - evocação e transferência de culturas". In: Arquiteturas da Memória, Manaus, 2007.

6. Dumas, Alexandre. Os Irmãos Corsos. São Paulo, Melhoramentos, 1964.

7. Texto a ser analisado em trabalho posterior.

\section{AUTEUR}

\section{ROSÂNGELA MARIA OLIVEIRA GUIMARÃES}

Pós-doutoranda do Programa de Pós-Graduação em Comunicação e Semiótica da PUC-SP, sob supervisão da Profa. Dra. Jerusa Pires Ferreira. Pesquisadora do Centro de Estudos da Oralidade do COS/PUC-SP/ Bolsista FAPESP. 